\title{
Financial Development and Economic Growth in Sub- Saharan Africa: A Dynamic Panel Data Analysis
}

\author{
By Elie Ngongang ${ }^{1}$ Ph.D
}

\begin{abstract}
Financial Development is the accumulation of financial assets at a rate that is more rapid than the rate of non-financial assets accumulation. Economic growth is the evolution of gross domestic product (GDP) in the short, medium and long terms. We have attempted in this paper to analyze and to verify empirically the controversy on the relationship between the financial sphere and the real sphere. From the data observed on 21 Sub-Saharan African (SSA) countries and by using the dynamic panel GMM technique, we were able to show that there exists a positive link between financial development and economic growth. This link is intense for the issue of the financial system in the space of Sub-Saharan Africa. However, an outcome highlighting an eventual link between foreign direct investment and economic growth is opportune.
\end{abstract}

Keywords: Real sphere - Financial sphere - Dynamic panel GMM - Sub-Saharan Africa.

\section{Introduction}

According to Shaw (1973), financial development is the accumulation of financial assets at a more rapid rate than the accumulation of non-financial assets. For Levine (2005), financial development occurs when financial instruments financiers, markets and financial intermediaries reduce, without necessarily eliminating them, the costs of obtaining information, the costs of executing contracts and the costs of transaction, and as a consequence, do a better job by offering financial functions. Economic growth is the evolution of Gross Domestic Product (GDP) in the short, medium and long term. It is the result of an increase in value-added produced by all the firms operating within a country. GDP is an aggregated value which takes account of all the value-added of all the firms operating on the national territory. The increase in the value-added during a given period means that the global wealth of a nation is rising. This manifests itself in the growth of per capita income and in a higher level of well-being.

In modern societies, economic growth is a considerable stake, and this was not the case in the old days. Political power takes this into consideration, for it conditions the living standards of the citizens. From the economic thought point of view, the last decades have been masked by a significant advance over the of the relationship between financial development and the real economic sphere. Two currents of thought come to intervene: the first show the positive impact of the development of the banking sector and of the financial market on economic growth, while the second exactly develops the opposite idea. The actions of opening and of stimulating the financial system and the banking system are at the origin of the financial instability and of the transmission (multiplication) of the banking crises which have manifested themselves by a degradation of economic growth which is due to the importance of the costs envisaged.

The potential positive impact of financial development on economic growth was originally analyzed by the authors of the financial repression school, that is to say McKinnon (1973) and 
Shaw (1973), and by other authors from the liberal school, notably Keynes $(1936,1937)$ and Hicks(1969). The latter have shown that an efficient, dynamic and modernized financial system is at the origin (or is a source) of capital accumulation, and of the stimulation of investment, and hence of economic development.

The harmful (unfavourable) impact of financial development (banking system and financial market) on economic growth was targeted starting from the recent banking and financial in the context of a financial liberalization policy.

On the one hand, according to Soltani et al. (2014), the robustness of the information asymmetry which characterizes financial markets, may be at the origin of a failure in the coordination of the allocation of savings to investment. This asymmetry of information may deform the anticipations of investors who prefer to invest in a less risky environment than in an environment which is uncertain and riskier. They do this by taking account of the degree of aversion to risk of investors, of the imperfection of financial markets and of the high level of transaction costs. These difficulties of the financial market and this ineffective intermediation can only slowdown economic growth.

On the other hand, from the point of view of facts, the recent crises of banking insolvency have thrown the economies into recessionary periods. This experience has given us an example of the negative impact of banking sector development on macroeconomic performance. These banking problems may transform themselves into banking or financial crises that may lead to enormous costs to the whole economy.

If from the theoretical point of view, the positive relationship between financial development and economic growth is beyond any doubt, some points however remain object of a debate: the controversy on the direction of causality and the structure of the financial system which favour growth better.

Our objective in this paper is to analyze and to verify empirically, the relationship that exists between financial development and economic growth in the context of the 21 Sub-Saharan African (SSA) countries during the period 2000-2014.

Two questions emerge from all these developments: - Is it financial development that causes economic growth? Or is it economic growth that leads to an expansion of the financial system? (Is the relationship between financial development and economic growth bi-uniform?). - Is a financial system based on the banks more efficient in the promotion of economic growth than a financial system based on financial markets? Several methods may be envisaged to answer these questions.

A possible method would consist of carrying out the analysis with the help of an error-correction model and the weak heterogeneity test (or a panel multivariate cointegrated model. As interesting as it may be, this method includes two main limits: (1) bivariate analysis suffers from the bias of omitted, and (2) times-series analysis requires relatively long series. Thus, despite its advantages, it restricts the approach to uncertainty. It is for this reason that we may keep (or use) the Generalized Moments method (GMM) of the panel dynamic of Arenallo and Bond (1991), which through different explanatory variables can justify the link between financial development and growth in the context of Sub-Saharan African (SSA) countries. This study is in line with this perspective.

The interest of this study is twofold: This has to do first, to innovate our methods in studying the importance of the relationship between financial development and growth, and to show that SSA countries must at present seek how to maximize the benefits of financial development while minimizing its costs and then, to underline the fact that financial development may contribute to providing the financial sector with a predominant place in the development policies of these countries. 
The first part of this paper presents the theoretical and empirical foundations of the nature of the link between financial development and economic growth, and then the second part exposes our econometric model, the results and the interpretations which result from these foundations.

1. Theoretical and Empirical Foundations of the Link between Financial Development and Economic Growth

The review of the literature on the relationship between financial development and economic growth is abundant and gives more importance to two aspects: theoretical and empirical.

\subsection{Theoretical Foundations}

The theoretical foundations of the relationship between financial development and economic growth are very old. They date back to the works of Schumpeter (1912), Gurley and Shaw (1960), Mckinnon (1973) and Shaw (1973). For Schumpeter, the smooth functioning of the banks stimulates technological innovation (through the identification and financing of businessmen, a brief source for stimulating growth). To achieve this objective, financial intermediaries must ensure the five main functions listed by Levine $(1997,2004) 1$; the line of argument of Gurley and Shaw (1960) is based on the importance of financial innovations in financial development. The latter authors explain the fact that new financial assets present fewer risks.

The theory of the relationship between financial development and growth has witnessed a renewal of interest during the 1990s. Studies were interested in confirming the link that exists between the financial sphere and the real sphere. The most famous works which mark current affairs are those of King and Levine (1993), Levine (1973). These authors show the important role of the banking system and of the financial market in the development of economic growth. They find a correlation between GDP (as indicator of growth) and the size of the financial system.

Beck and Levine (2002) also prove that the development of the banking system and of the financial market may lead to the development of economic growth, provided a few conditions are respected. This has to do with a smooth functioning of the financial system, a weak information asymmetry, a low transaction cost, and an optimal allocation of resources.

Caporale et al. (2004) in their joint works on the development of the financial market and economic development, find that a smooth functioning of the financial market may favour growth. Similarly in the context of China, Shan and Jianhong (2006) argue that the contribution of financial development to economic growth is interpreted as the second force after the contribution of the incomes of workers. According to the authors, the link between financial sphere and economic sphere has a double sense of causality. The development of the financial system (development of the banking system: distribution of credits to finance investments) provides nominal GDP growth. They also maintain that the strong economic growth registered in recent years, has a significant impact on the development of the financial system.

\subsection{Empirical Foundations}

Using a sample of 74 developed and developing countries, Beck et al. (2000) use two methodological approaches to take account of the endogeneity of the financial development variable in a growth model over the period 1960-1995. Firstly, they carry out a transversal analysis by instrumenting financial development by the Anglo-Saxon, French, Germanic and Scandinavian origin of the law. Then, by keeping the same instrumental variable, they carry out a dynamic panel analysis, with a division into seven periods of five years using the Generalized Method of Moments (GMMs) estimator, a method that makes it possible to solve the inverted causality problem, for instance. These authors conclude for the existence of a positive link between the exogenous component of financial development and economic growth. However, this favourable relationship goes by the increase in the global productivity of factors, rather than 
over the volume of savings and the accumulation of capital. These results are also confirmed by Rioja and Valev (2003) in their research studies on finance and the sources of economic growth. In another more recent paper, Beck and Levine (2006) consider financial development under a more global angle. They simultaneously examine the role of the development of banking activities and that of the development of stock exchange markets on growth. The study is carried out using a large sample of 40 countries with panel data on the average over the long period 1976-1998. The results obtained with the help of the method of Generalized Moments in dynamic panel show that the development level of the banks (measured by the ratio of credits to the private sector in proportion of GDP) and the development level of stock exchange markets (measured by the turnover ratio) independently exercise each a positive impact on economic growth. King and Levine (1993) use the measures of the size of the banking financial intermediaries as an indicator of financial development with a positive effect. For these authors, it is a question of a measure of the total size of the financial sector. Although this indicator has the advantage of being largely available for a number of countries, it has the drawback of being unable to capture the allocation of capital in the economy, to efficiently reflect the prediction of financial services in the economy, and to distinguish the private sector from the public sector.

To sum up, despite the important role of financial development in the growth process, some recent research studies show that there exist other sources of growth such as public expenditures, human capital investments, and expenditures on research and development, and technological innovation, etc.

With his precursory works on the relationship between financial development and growth, Goldsmith (1969) studies the financial evolution of 35 mostly industrialized counties over the long period going from 1861 to 1963). He shows that the development of these countries is accompanied by an upward trend in the financial assets to real capital ratio (called FIR or Financial inter-relationships ratio) and in terms of flows, the ratio of the issue of financial assets to GDP. This study by Goldsmith presents a few weak points: the observations are limited to only 35 countries, economic growth is not controlled for the impacts of the other factors which determine it, and the double causality between financial development and growth is not taken into account.

Luintel and Kaln (1999) analyze the long-term relationship between financial development and economic growth on the basis of multivariate VAR models, using a sample of 90 countries over the period 1950-1994. They find a double-causality link between the variables of each of the countries of the sample. Christopoulos and Tsionas (2004) use a sample of 10 countries to estimate, with the help of a model of multivariate cointegration in panel, and find results which support the existence of a long-term causality which goes from financial development to economic growth. Thus, we come back again to the results obtained by King and Levine (1993). The link between financial development and growth was also analyzed at the sectoral level. Rajan and Zingales (1998) used industrial data to study the mechanism through which financial development may influence growth. These authors defend the idea that financial development reduces the market imperfections which constrain access to credits by entreprises. As a consequence, industries whose demands of external capital are the largest must benefit disproportionately from financial development. This implies that industries with strong a need of external capital must grow faster in economies that are the most financially developed than in economies with a low level of financial development. Using panel data on the different industrial sectors of 41 countries (annual data over the period 1980-1990), the results show that financial development has an impact that is all the stronger on the average growth rate of value-added of a sector, because the need for financing of this sector is important, a situation which supports the hypothesis that financial development stimulate economic growth by reducing the financing constraints of entreprises. 
In spite of the multitude of research works which find a positive relationship between financial development and economic performance, a new emerging literature calls the robustness of this relationship into question. Thus Anderson and Trap (2003) 2 have shown that the positive relationship between financial development and the growth rate of the product per head, and, brought to light by Levine, Loayza and Beck(2000) 3 is no longer borne out when their sample is only restricted to developing countries, because these countries witnessed crises during the 1980s, when they liberated their financial sectors and put more rapid liberalization reforms in place. They also consider that studies on time serie belonging to a specific country, do not clearly a causality going from financial development to growth. These authors conclude that the positive impact of financial development on growth is not analyzed enough by empirical studies.

Favara (2003) has elaborated a study on the relationship between finance and growth from and empirical point of view, and has presented results based on cross-section data and panel data with a variety of econometric methods. He uses two indicators which measure financial development, that is to say liquid assets credits to the private sector. With the help of the method on the crosssection data, financial development appears to be positively correlated to growth, But his relationship disappears when one tries to examine the endogeneity of financial development, for instance, through the legal origin as instrument (according to Kangni (2006)), while with the method of generalized moments financial development becomes insignificant in the growth equation.

Aghion, Howitt and Mayer-Foulkes (2004) have also found an insignificant direct impact of financial development (measured by credit/GDP) on economic growth. But the coefficients of the crossed- variable of the financial development level and of the initial level of GDP per head (relative to that of the United States), presents a negative and significant sign. The authors conclude that the probability of a country to converge on the growth rate of the American economy increases with the level of financial development. There exists a critical financial development threshold beyond which all the countries converge on the growth rate of the American economy, while the economies of countries situated below this critical threshold do not converge, and they have a growth rate that is clearly smaller.

All in all, the authors highlight an ambiguous relationship between financial development and economic growth. The level of credits as a percentage of GDP influences growth only in the intermediary stages of development.

Emmanuel (2007) re-examine the link between financial development and growth from the empirical point of view of 22 countries of Sub-Saharan African countries during the period 19602002. The author considers that the positive and significant correlation between the indicators of financial development (represented by the ratio of the money supply M2 to GDP and the ratio of credit to the private sector to GDP and the growth of GDP per head is ambivalent. In addition, the relation of causality varies in the sense between bidirectional and unidirectional going from financial development to economic growth.

Soltani et al. (2014) show through the method of generalized moments (GMM) on a sample of 11 countries of the region of MENA4 (during the period 1995-2011) that financial development is detrimental to economic growth in this region.

Finally, some authors, (notably, Gregorio and Guidotti, 1992 ; Fernandez and Galetovic, 1994 ; Ram, 1999 ; and Favara, 2003) suggest that the relationship between financial development and economic development could be less general than the traditional literature thinks, and they underline the fact that the results of econometric studies vary as a function of the sample and of the period condisidered.

From the preceding, rather than formulating a panel multivariate cointegrated model, we will use the dynamic panel GMM econometric method. 


\section{The Econometric Approach and Interpretations of the Results}

The main objective of this paper is to analyze and to empirically confirm the link that exists between financial development and economic growth in the context of Sub-Saharan African (SSA) countries 5. To achieve this, we have chosen 21 SSA countries observed during the 2000-2014. This choice is justified by the availability of the database of the World Bank (2014). In addition, some of the data of the variables are the compilations obtained from other sources 6. The econometric method used is the dynamic panel GMM method.

\subsection{Specification of the Model}

There exists a multitude of econometric models which deal with the link between financial development and economic growth. Because of this, our choice of a model rests on the existence of variables, insofar as we are going to try in this empirical part the study to establish the link between financial development and economic growth in the Sub-Saharan African context.

By referring to the works of Samy and Samir (2007) which were revisited by Soltani et al. (2014), our model may be written in the following form:

$$
\begin{aligned}
& \operatorname{TGDP}_{j, t}=\alpha_{0}+\alpha_{1} \mathrm{CBBSP}_{j, t}+\alpha_{2} \mathrm{CBPH}{ }_{j, t}+\alpha_{3} \mathrm{IC}_{j, t}+\alpha_{4} L F_{j, t} \\
& +\alpha_{5} \text { TOXM }_{j, t}+\alpha_{6} \mathrm{INF}_{j, t}+\alpha_{7} I P_{j, t}+\varepsilon_{j, t}
\end{aligned}
$$

Where, $T G D P_{j, t}=$ the growth rate of real GDP per head; $C B B S P_{j, t}=$ banking credit to the private sector relative to GDP, $C B P H_{j, t}=$ stock market capitalization relative to GDP per head; $I C_{j, t}=$ dummy variable which reflects corruption; $L F_{j, t}=$ dummy variable, reflecting financial liberalization; $T O X M_{j, t}=$ openness rate measured by total exports $(\mathrm{X})$ and imports $(\mathrm{M})$, as a percentage of GDP ; $I N F_{j, t}=$ inflation rate; $I P_{j, t}=$ dummy variable, reflecting political instability; $\varepsilon_{j}=$ random variables; $t=$ years that vary from 1 to $14 ; j=$ counties that vary from 1 to 21 .

To control for specific individual and temporal effects as well as to compensate for the problem of the endogeneity of the variables, we use the estimator of Arellano and Bond (1991) which consists of taking for each period, the first difference of the equation to be estimated to eliminate the specific effects of each country, as well as to instrument the lagged explanatory variables. In our model, the lagged variable is that of GDP. Our model may therefore be written as follows:

$$
\begin{aligned}
& \operatorname{TGDP}_{j, t}=\alpha_{0}+\alpha_{1} \mathrm{TGDP}_{j, t-1}+\alpha_{2} \mathrm{CBBSP}_{j, t}+\alpha_{3} \mathrm{CBPH}_{j, t}+\alpha_{4} I 2 C_{j, t} j, t+\alpha_{5} L F_{j, t} \\
& +\alpha_{6} \mathrm{TOXM}_{j, t}+\alpha_{7} I N F_{j, t}+\alpha_{8} I P_{j, t}+\varepsilon_{j}
\end{aligned}
$$

With $T G D P_{j, t-1}=$ the growth rate of lagged real GDP per head

\subsection{Results and Interpretations}

We used the dynamic panel method of generalized moments (GMM) with the help of the software package STATA 11.0 to estimate Equation 2 through the estimator of Arellano and Bond (1991). The results of our estimation are presented in Table 1 below. 
Table 1: Panel Dynamic GMM Regression of the Dependent Variable (TGDP)

\begin{tabular}{|c|c|c|c|c|}
\hline Variables & Coefficient & Std.Err & $\mathrm{Z}$ & $\mathrm{P}>[\mathrm{Z}]$ \\
\hline$C$ & 8.998019 & 2.600115 & 4.44 & 0 \\
\hline TGDP & 0.160914 & 0.093417 & 3.11 & 0.017 \\
\hline CBBSP & - 0.067821 & 0.028702 & -4.0 & 0 \\
\hline СВРН & 0.005611 & 0.008998 & 0.5 & 0.543 \\
\hline IC & -1.300443 & 0.960098 & -1.36 & 0.211 \\
\hline$L F$ & -1.622116 & 3.102031 & -0.59 & 0.549 \\
\hline TOXM & 0.051015 & 0.055812 & 0.94 & 0.388 \\
\hline$I N F$ & - 0.022114 & 0.033568 & -0.83 & 0.471 \\
\hline IP & - 4.008761 & 1.181125 & -2.73 & 0.009 \\
\hline Wald chi2 (8) & \multicolumn{4}{|c|}{57.88} \\
\hline Prob> ch2 & \multicolumn{4}{|c|}{0} \\
\hline $\mathrm{Nb}$ of instruments & \multicolumn{4}{|c|}{231} \\
\hline
\end{tabular}

Sources:

Table 1 summarizes the regression results of the financial development indicators (stock market capitalization relative to real GDP per bead (CBPH) and banking credit to the private sector relative to GDP (CRBSP) over economic growth after control of the equation by a certain number of macroeconomic variables (the rate of inflation, the rate of openness, financial liberalization, political instability and the corruption index). We note from Table 1 that there are explanatory variables which are statistically significant, while others are not, and afterwards which do not have an impact on our endogenous variable.

The variable $\left(T G D P_{t-1}\right)$ is positively and significantly correlated with our variable to be explained ( $\left.T G D P_{t}\right)$. In other words, the growth rate of real GDP per head of year $(\mathrm{t})$ depends positively and significantly on that of year ( $\mathrm{t}-1)$.

Similarly, we note that the coefficient of the level of credits (CBBSP) distributed by the banks and other financial institutions to the private sector is significantly negative. This observation may be directly linked to the predominant public sector in Sub-Saharan Africa in the allocation of credits. Consequently, to improve the process of credit allocation, Sub-Saharan Africa (SSA) countries need to accelerate the privatization of national banks or the reinforcement of the reglementation of credit and the promotion of competition in the banking sector.

Moreover, from the weak coefficient $(0.56 \%)$, the results of our estimation show that the stock market capitalization positively and insignificantly impacts on the growth rate of GDP per head. This result may be explained by the high level of financial repression and the presence of a weak stock market which is incapable of supporting a durable economic development in SSA countries, in addition to the presence of slow and unbalanced growth, which weakens any relationship between financial development and economic growth, as underlined by Soltani et al. (2014) in the case of countries of MENA.

Similarly, the trade openness of SSA countries has a positive and insignificant impact on economic growth. This proves that the increased mobilization of savings and the best allocation of resources in the economy permit an extension of production possibilities and the adoption of more efficient techniques, which reinforce specialization, technological innovation and economic growth.

As concerns the impact of financial liberalization, the variable (LF) negatively and insignificantly affects the growth rate of real GDP per head. To justify this negative relationship between financial liberalization and economic growth in the context of SSA countries, we may mention the fact that a third of the countries in our sample did not undertake the process of financial openness. In addition, the countries that opted for programs of liberalization did so partially and 
gradually as in the case of countries of Central and West Africa. Similarly, this result is conditioned by an unstable macroeconomic environment, detected by this regression from the coefficient of political instability (PI) which is significantly negative, as it is shown in the theoretical and empirical literature which is contradictory to that of McKinnon (1973) and Shaw (1973). In the same vein, we obtained negative signs for the variables of corruption (IC) and of inflation (INF). This encourages SSA countries in presence to search for an environment characterized by stability at the political and economic levels.

\section{Conclusion}

The objective of this paper was to analyze and to verify empirically the relationship between financial development and economic growth, using a sample of 21 SSA countries during the period 2000-2014. We simultaneously tested the independent impact of the stock market and banking development on economic growth. Our regressions which were carried out using the estimator of Arenallo and Bond (1991) according to the method of generalized moments (GMM), and through different explanatory variables show that financial development is without effect on economic growth. This result must be justified by reference to theory. This absence of the relationship might be linked to the under-developed financial systems of Sub-Saharan Africa which hinder growth, or to the instability of the growth rates of real GDP per head in the SubSaharan space which affect the quality of the relationship between finance and economic growth.

From the political point of view, it is evident that an improvement in the performance of the financial system in the sub-region is indispensable in order for financial development to stimulate growth. Thus, these countries need to enhance the process of credit allocation, first through the acceleration of the promotion of the privatization of national banks; then through the regulation of credits, and lastly through the reinforcement of competition in the banking sector. However, a preliminary condition is that the regulatory infrastructure should be well-developed and measures should be taken to reduce the extreme volatility of the pries of assets in order to make it possible for the stock market to stimulate economic growth in Sub-Saharan Africa. Thus, as a consequence, financial development could affect the relationship between foreign direct investments and economic growth.

\section{Notes}

1. The five functions of Levine are: a) To acquire information on the projects and to promote the optimal allocation of resources; b) To facilitate financial and commercial transactions, the management of risks and the diversification of assets; c) To ensure the supervision of investments, to exercise control over the management of entreprises after the financing of projects; d) Ensure the mobilization of savings; and e) To facilitate the trade of goods and services.

2. Guillaumont and Kpodar (2004)

3. Kangni (2006)

4. The MENA region regroups the following countries: Morocco, Tunisia, Algeria, Saoudie Saudi, Bahrain, the West Bank and Gaza, Djibouti, Egypt, UAE, Iran, Iraq, Jordan, Kuwait, Lebanon, Libya, Malta, Oman

5. Sub-Saharan African (SSA) countries

6. Other data sources: http:// data.World Bank.org

\section{References}

Aghion, P., Howitt P., \& D. Mayer-Foulkes. (2004).’'The Effect of Financial Development on Convergence: Theory and Evidence", NBER Working Paper 10358.

Anderson, T. et F. Tarp. (2003). "Financial Liberalization, Financial Development and Economic Growth in LDGs", Journal of International Development, Vol. 15, n0 2, PP. 189-209. 
Arellano, M and S. Bond. (1999a). "Some Tests of Specification for Panel Data, Review of Economic Studies", Vol. 58, n0 2, PP. 277-97.

Arellano, M. and S. Bond . (1991b). "Some Tests of Specification for Panel Data: Monte Carla Evidence and an application to employment Equations", Review of Economics Studies. Vol, 58, n0 2, PP. 277-297. Http//: www. Jstor.org/stable/ 2297968.

Baltagi, B.H, Demertriades, P.O. and S.H Law. (2009). "Financial Development and Openness: Evidence from Panel Data", Journal of Development Economics, Vol. 89, PP 285-296.

Beck, T. and R. Levine. (2004). "Stocvk Markets, Bank and Growth: Panel Evidence", Journal of Bank Finance, Vol. 28, pp. 423-442.

Beck, T., Levine R. and N. Loayza.(2000). "Finance and the Sources of Growth", Journal of Financial Economics. Vol. 58, n0 1et 2, PP. 261-300.

Bencivenga , V. et B. Smith. (1991). "Financial Intermediation and Endogenous Growth", Review of Economics Studies, Vol. 58, n02, PP.195-209.

Boyd J.H, R. Levine and B.D. Smith. (2000). "The Impact of Inflation on Financial Sector Performance", Journal of Monetary Economics, Forthcoming.

Blundell R. et S. Bond. (1997)."Initial Conditions and Moment Restrictions in Dynamics PANEL Data Models", Decisions Paper, n0-97-07, University College London.

Caporale G. M., P.G.A. Howells and A. M. Soliman. (2004). "Stock Market Development and Economic Growth: the Causal Linkage", Journal of Economic Development,

Christopoulos, D. and E. Tsionas. (2004). "Financial Development and Economic Growth: Evidence from Panel Unit Root and Cointegration Tests", Journal of Development Economics, Vol. 73, no 1, PP. 55-74.

Easterly, W. R. Gatti and S. Kurlat. (2006). "Development, Democracy, and Mass Killings", Journal of Economics Growth, Vol. 11, PP. 129-156.

Emmanuel, A. (2007). "Développement financier, croissance économique et productivité globale des facteurs en Afrique Subsaharienne", Université de Cocody- Abidjan.

Favara, G. (2003). An Empirical Reassessment of the Relationship between Finance and Growth, IMF Working Paper, N0.03/123,Vol. 48, PP. 1-47, Available at ssrn.com/abstract=879199, Januray 30, 2006.

Fernandez, D. et A. Galetovic. (1994)." Schumpeter might be Right-Buy Why? Explaining the Relation between Finance, Development, and Growth", Johns Hopkings University Sais Working Paper in International Economics, no 96-01.

Goldsmith R.W. (1969). Financial Structure and Development, New York, Yale University Press.

Guillaumont- Jeanneney, S. (1998).Monnaie et finance. Puf, Paris.

Guillaumont Jeannency, S.G K.R. Kpodar. (2004). "Développement financier, instabilité financière et croissance économique". Document de travail de la série Études et Documents.

Gurley J.G. and E.S. Shaw .(1960). La monnaie dans une théorie des actifs financiers, traduit par le centre de Traduction économique de Perpignan, Edition Cujas, 1974.

Gregorio (de) J. and P. Guidotti .(1992). "Financial Development and Economic Growth", IMF Working Paper 92/101, International Monetary Fund.

Hicks, J. (1969). A Theory of Economic History. Clarendon Press, Oxford.

Jones, G. and W.J. (2006). "Intelligence, Human Capital, and Economic Growth: A Bayesian Averaging of Classical Estimates (BACE) Approach”, Journal of Economic Growth, Vol.11. PP. 71-93.

Kangni, K. (2006). Développement, instabilité financière et croissance économique: implications pour la réduction de la pauvreté, Thèse de Doctorat, CERDI, Université d'auvergne- Clermont I, P. 341.

Keynes, J. M. (1936). Théorie générale de l'emploi, de l'intérêt et de la monnaie, Paris, édition Payot, 1942.

Keynes, J.M. (1937). "The Ex-ante Theory of the Rate of Interest", The Economic Journal, dans The General Theory and after, Part II, Defence and Development, Macmillan for the Royal Society, PP. 215-223.

King, R. et R. Levine. (1993)."Finance, Entrepreneurship, and Growth: Theory and Evidence", Journal of Monetary Economics, Vol. 32, PP. 513-542.

King, R. et R. Levine. (1993). "Financial Intermediation and Economic Development" in Financial Intermediation in the Construction of Europe, Eds: Mayer C. and Vives X, London: Centre for Economic Policy Research, PP. 156-189. 
King, R.G. and R. Levine. (1993). "Finance and Growth: Schumpeter might be right". Quart Journal Economic, Vol. 108, PP. 717-738.

Levine, R. (2004).'Finance Growth, Theory, Evidence, and Mechanism", in Hanbook of Economic Review, Vol. 88, n0 3, PP. 537-558.

Levine, R. (1997)."Financial Development and Economic Growth: Views and Agenda", Journal of Economic Literature, Vol. 35, n0 2, PP. 688-726.

Levine R., Loayza N. et T. Beck. (2000)." Financial Intermediation and Economic Growth: Causality and Causes", Journal of Monetary Economics, Vol. 46, n0 1, PP. 31-77.

Luintel, K. and M. Kaln. (1999). "A Quantitative Reassessment of the Finance- Growth Nexus: Evidence from Multivariate VAR”, Journal of Development Economics, Vol. 60. PP. 381-405.

Mckinnnon, R. (1973). "Money and Capital in Economic Development", Washington Dc Booking Institution.

Mckinnon R. I. (1973). Money and Capital in Economic Development, The Brooking Institution

Ram, R. (1999)." Financial Development and Economic Growth: Additional Evidence", Journal of Development Studies. Vol. 3, n0 4, PP. 164-174.

Rajan, R. et L. Zingales. (1998). "Financial Dependence and Growth". American Economic Review. Vol. 88, n0 3, PP. 559-86.

Rioja, F. and N. Valev .(2004). Finance and the Sources of Growth at Various Stages of Economic Development. Economy Inquiry, Vol. 42. N).1, PP. 127-140.

Samy, N. and G. Samir. (2007). "Stock Markets, Banks, and Economic Growth Empirical Evidence from the MENA Region". Research in International Business and Finance, Vol. 21. PP. 297-315.

Schumpeter, J. (1912). The Theory of Economic Development. Leipzig Dunker \& Aumblot, Translate by Redvers Opie, Cambridge, MA: Harvard University Press, 1994.

Shaw, E. S. (1973). Financial Deepening in Economic Development. Oxford University Press.

Shaw, S. Edward. (1973). "Financial Deepening in Economic Development", New York: Oxford University Press.

Shaw, J. and Q. Jianhong .(2006). "Does Financial Development Lead Economic Growth? The case of China". Annuals of Economics and Finance, Vol. 1, PP. 231-250.

Soltani, H., Ochi A. and Y. Saidi. (2014). "Développement financier et croissance économique: cas de la région MENA". Volume Book : Economics \& Strategic Management of Business Process, Vol. 2. PP. 40-44.

Soltani ,H., Ochi,A.(2012). "Foreign Direct Investment (FDI) and Economic Growth: an Approach in terms of Cointegration for the case of Tunisia", Journal of Applied Finance \& Banking, Vol. 2, no 4, PP.193-207. 